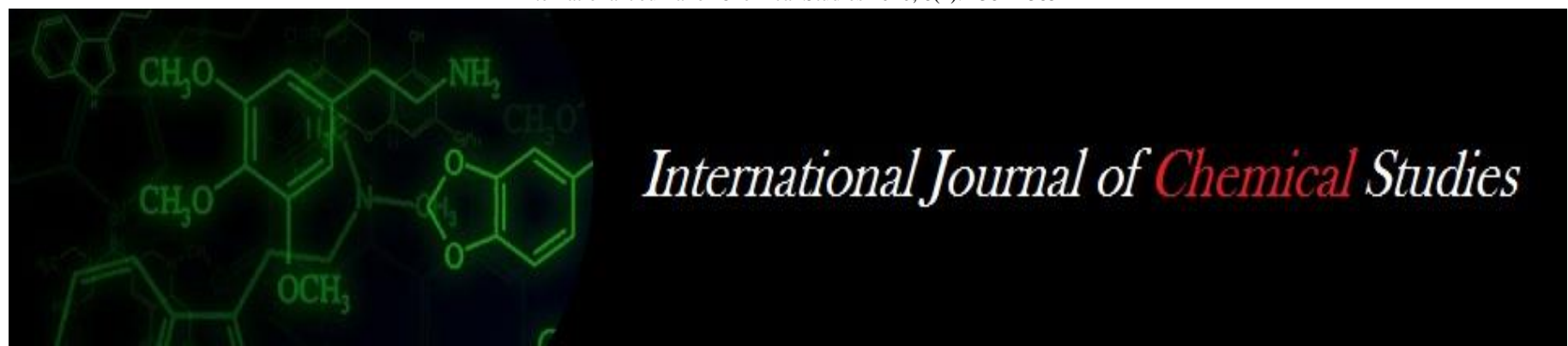

P-ISSN: 2349-8528

E-ISSN: 2321-4902

IJCS 2020; 8(1): 1382-1385

(C) 2020 IJCS

Received: 28-11-2019

Accepted: 30-12-2019

\section{BS Gunjal}

Department of Agronomy, Mahatma Phule Krishi

Vidyapeeth, Rahuri Dist.

Ahmednagar, Maharashtra

State, India

\section{SP Shinde}

Department of Agronomy,

Mahatma Phule Krishi

Vidyapeeth, Rahuri Dist.

Ahmednagar, Maharashtra

State, India

\section{SS Chitodkar}

Department of Agronomy,

Mahatma Phule Krishi

Vidyapeeth, Rahuri Dist.

Ahmednagar, Maharashtra State, India
Corresponding Author: BS Gunjal

Department of Agronomy, Mahatma Phule Krishi Vidyapeeth, Rahuri Dist. Ahmednagar, Maharashtra State, India

\section{Energy studies of sweet corn-potato cropping sequence under integrated nutrient management}

\author{
BS Gunjal, SP Shinde and SS Chitodkar
}

DOI: https://doi.org/10.22271/chemi.2020.v8.i1s.8448

\begin{abstract}
The present investigation was conducted for kharif and rabi season on sweet corn-potato cropping system for two consecutive years (2014-15 and 2015-16) in a clayey in texture soil at the Post Graduate Institute Research Farm, M.P.K.V., Rahuri (Maharashtra) India. To evaluate the energy studies of sweet cornpotato cropping sequence under integrated nutrient management. The results revealed that significant enhancement in the energy output (457541, 468162 and $462852 \mathrm{MJ}^{-{ }^{-1}}$ ), energy balance (385966, 396152 and $\left.391059 \mathrm{MJ} \mathrm{ha}^{-1}\right)$, energy balance per unit input (5.39, 5.50 and 5.45 $\left.\mathrm{MJ} \mathrm{ha}^{-1}\right)$ and energy use efficiency $\left(6.39,6.50\right.$ and $\left.6.45 \mathrm{MJ} \mathrm{ha}^{-1}\right)$ of the sweet corn-potato cropping system with the application of treatment $\mathrm{T}_{7}-125 \% \mathrm{RDN}+25 \% \mathrm{~N}$ through vermicompost during the period of study. Thus, use of organic sources vermicompost significantly improved the Energy output, energy balance per unit input and energy use efficiency of the sweet corn-potato cropping system.
\end{abstract}

Keywords: Sweet corn-potato cropping system, energy output, energy balance, energy balance per unit input, energy output per unit input ratio

\section{Introduction}

Maize has high genetic yield potential than other cereal crops. Hence it is called as 'miracle crop' and also as 'queen of cereals'. The sweet corn-potato cropping sequence has the highest nutrient requirement; however, it is most attractive system in terms of economics returns and energy efficiency (Vyas et al., 2012) ${ }^{[4]}$. In India, after the green revolution, intensive agriculture involving exhaustive high yielding varieties has lead to heavy withdrawal of nutrients from the soil. The imbalanced use of chemical fertilizers by farmers has deteriorated soil health. The organic sources of nutrients helps in improving and maintaining soil health for enhancing and sustaining agricultural production (Meena et al., 2011) ${ }^{[6]}$. In India, agriculture not only provides food for all, but also employment to $70 \%$ of the population, which generates $40 \%$ of the national income and consumes about $10 \%$ of the commercial forms of energy. Energy is a critical aspect of a national development process it is also expended in agricultural operations. Crop cultivation requires application of both animal and inanimate forms of energy at different stages. Nutrients are provided through organic manure, chemical fertilizer or both. Seed, manures, labour and draft animal can be termed as integrated nutrient management (INM), a combined application of organic and inorganic sources of nutrients, maintains storage of plant nutrients in soil and improves nutrients-use efficiency that is essential for sustainable crop production. Organic matter acts as a source and a sink for plant nutrients as well as provides energy substrate for soil micro--organisms. Thus, it enhances activities of soil flora and fauna as well as intrinsic soil properties, soil nutrient capital, water-holding capacity and soil structure in turn makes soil less susceptible to leaching and erosion. Therefore, INM practices are essential to maintain/enhance the soil quality and sustainability of an agroecosystem (Zeidan, 2007) ${ }^{[8]}$. Kharif maize often face terminal drought resulted crop failure or very less productivity. It may be overcome by growing the maize for sweet corn instead of green cob. Besides farmyard manure (FYM), now-a-days vermicompost is gaining attention of both the researchers and the farmers due to its immense production potential using farm. Nutrients are one of the most important inputs, required by the plants for their growth and yield. The organic manures is considered as the promising renewable source of energy, nutrient rich source and can be served as a substitute to cut down the cost of fertilizer input and to increase the productivity in addition to maintain soil productivity, improve the eco-system 
and ultimately resulting in improved soil-plant-health in a sustainable agricultural eco-system. Keeping this in view, the present investigation was taken up to study the effect of integrated nutrient management on sweet corn - potato cropping system and its energy balance since limited information is available pertaining to this.

\section{Material and methods}

A field experiment was conducted from 2014 to 2015 at the Post Graduate Institute Research Farm, of Mahatma Phule Krishi Vidyapeeth, Rahuri is lies between 190 48'N and 190 57'N Latitude and 740 32'E and 740 19'E longitude. The altitude varies from 495 to 569 meters above mean sea level. This tract is lying on the Eastern side of Western Ghat and falls under rain shadow area. Climatologically, it falls in semi arid tropics with an annual rainfall varying from 307 to 619 $\mathrm{mm}$. The average annual precipitation is $520 \mathrm{~mm}$. Out of the total annual rainfall, about 80 per cent rains are received from South - West monsoon (June to September), while rest receives from North - East monsoon. The number of rainy days varies from 15-45 in a year. The mean annual maximum and minimum temperature ranges from $330 \mathrm{C}$ to $430 \mathrm{C}$ and 3 $0 \mathrm{C}$ to $180 \mathrm{C}$, respectively. The mean relative humidity during morning and evening hours is 59 and 35 per cent, respectively. The mean pan evaporation ranges from 5.3 to $12.1 \mathrm{~mm}$ and the sunshine hours ranges from 7 to 9 day $^{-1}$. The soil of experimental site was sandy loam with bulk density of $1.39 \mathrm{Mg} \mathrm{m}-3$. In soil organic carbon was 0.51 with $241.35 \mathrm{~kg}$ ha- 1 available $\mathrm{N}, 22.85 \mathrm{~kg}$ ha- 1 available $\mathrm{P}, 365.75 \mathrm{~kg}$ ha-1 available $\mathrm{K}$ in first year, respectively. The $\mathrm{pH}$ was 8.20 with EC of $0.33 \mathrm{dSm}$ respectively. The experiment included two crops per year, namely, kharif sweet corn (July-November), winter potato (November- March).The field trial was conducted on the same field and on same layout without changing randomization during both the years. The experiment was laid out in Randomized Block Design, during kharif season the main plot treatments comprised of the gross recommended dose of fertilizers and three levels of FYM and vermicompost to sweet corn, replicated thrice and during rabi season each sub plot treatment was divided into two sub plot treatments with two levels of the gross recommended dose of fertilizers to potato. Thus, during rabi season there were fourteen treatments comprised of seven main plot treatment of FYM and vermicompost and two sub plot treatments comprised of two levels of fertilizer to potato replicated thrice in split plot design. The recommended dose of NPK in sweet corn was applied through urea, single super phosphate and muriate of potash, respectively. The nitrogen was applied into three split (1/3 each as basal, tasseling and grain formation stage). The full dose of $\mathrm{P}$ and $\mathrm{K}$ was applied as basal. The treatment consisted $\mathrm{T}_{1}-100 \% \mathrm{GRDF}, \mathrm{T}_{2}-75 \% \mathrm{RDN}+25 \%$ $\mathrm{N}$ through FYM, $\mathrm{T}_{3}-75 \% \mathrm{RDN}+25 \% \mathrm{~N}$ through $\mathrm{VC}, \mathrm{T}_{4}-$ $100 \% \mathrm{RDN}+25 \% \mathrm{~N}$ through FYM T $5-100 \% \mathrm{RDN}+25 \% \mathrm{~N}$ through VC, $\mathrm{T}_{6}-125 \% \mathrm{RDN}+25 \% \mathrm{~N}$ through $\mathrm{FYM}$ and $\mathrm{T}_{7}$ $-125 \% \mathrm{RDN}+25 \% \mathrm{~N}$ through $\mathrm{VC}$ for kharif sweet corn as a main plot treatment, whereas for rabi potato two sub plot treatment levels of GRDF viz., F1 - 75\% GRDF and F2 $100 \%$ GRDF replicated two times in split plot design resulting in seven treatment combinations replicated thrice during kharif season and fourteen treatment combinations during rabi season in RBD-split plot design replicated thrice. The experiment was conducted on same site without changing the randomization of the treatments for successive years. The required quantity of different manures viz. vermicompost and FYM as per the treatments was applied in field ten days before sowing of both the crops. The available $\mathrm{N}, \mathrm{P}$ and $\mathrm{K}$ content were $1.02,0.50$ and $0.80 \%$ in vermicompost, 0.50 , 0.20 , and $0.44 \%$ in FYM. In doing so the respective contribution of $\mathrm{P}$ and $\mathrm{K}$ from vermicompost and FYM was also considered. The fertilizers used were urea for $\mathrm{N}$, single superphosphate for $\mathrm{P}$, and muriate of potash for $\mathrm{K}$. The seed of of sweet corn var. Suger-75 was dibbled on the ridge sides at a spacing of $20 \mathrm{~cm}$ at $4 \mathrm{~cm}$ depth and required plant population $(83,000$ plant ha-1) was maintained by thinning of plants after one week of germination. Similarly, potato var. K. Jyoti seed tubers of $25-30 \mathrm{~cm}$ size were sown $5 \mathrm{~cm}$ deep on the south side of the ridges at a spacing of $20 \mathrm{~cm}$ between tubers in rainy and winter seasons respectively. The energy input, energy output, energy balance per unit inputs and energy input output ratio ( $\mathrm{MJ} \mathrm{ha}^{-1}$ ) of the system were worked out. The energy input was worked out by using the item wise energy values for each treatment and expressed as $\mathrm{MJha}^{-1}$. The energy output from sweet corn and potato of respective crop was worked out by multiplying yields (calorific value of harvested biomass of sweet corn and potato) with their energy values for respective crop i.e., sweet corn and potato and expressed as $\mathrm{MJ} \mathrm{ha}^{-1}$. The energy balance was worked out by deducting the energy input from the energy output for each treatment and expressed as $\mathrm{MJ} \mathrm{ha}^{-1}$. Energy balance per unit input $\left(\mathrm{MJ} \mathrm{ha}^{-1}\right)$ was calculated as - energy balance dividing energy input The energy output per unit input ratio ( $\mathrm{MJ} \mathrm{ha}^{-1}$ ) was estimated by dividing energy output values with input values. Energy use efficiency (MJ ha ${ }^{-1}$ worked out as energy balance divided by energy input.

\section{Results and discussion Productivity: Yield}

The data on biomass yield of sweet corn and potato at harvest as influenced by different treatments are presented in Table 1. The treatment $\mathrm{T}_{7}-125 \% \mathrm{RDN}+25 \% \mathrm{~N}$ through $\mathrm{VC}$ proved its superiority in recording higher green cob $(275.55,281.55 \mathrm{q}$ $\left.\mathrm{ha}^{-1}\right)$ and green fodder yield $\left(542.83,554.19 \mathrm{q} \mathrm{ha}^{-1}\right){ }^{1}$ respectively than other fertilizer levels. The higher yield observed with the application of vermicompost in comparison to FYM may be explained on the basis of higher nutrient content, faster decomposition and released nutrients in vermicompost besides enhancing the microbial population and higher root biomass (Kannan et al., 2005) ${ }^{[5]}$. Similarly, the treatment $\mathrm{T}_{1}-100 \%$ GRDF recorded significantly maximum in terms of tuber yield $\left(280.21,286.96 \mathrm{q} \mathrm{ha}^{-1}\right)$ and haulm yield $\left(12.31,13.52 \mathrm{q} \mathrm{ha}^{-1}\right)$ than rest of other treatments. The superiority of FYM was attributed to its slow decomposition (Singh et al., 1996) ${ }^{[7]}$, which caused immobilization of nitrogen and low availability of nitrogen for the sweet corn crop found to be reversed during the succeeding potato crop.

\section{Energy studies of cropping sequence}

The data pertaining to the total energy output, total energy input, total energy balance ( $\mathrm{MJ} \mathrm{ha}^{-1}$ ) and total energy balance per unit input and total energy use efficiency of sweet cornpotato cropping sequence during first year, second year and pooled mean over years as influenced by different treatments are presented in Table 2.

\section{Energy Study: Energy output}

The different fertilizer levels to preceding sweet corn affected the total energy output significantly during both years and in pooled mean. The treatment $\mathrm{T}_{7}-125 \% \mathrm{RDN}+25 \% \mathrm{~N}$ through VC (457541, 468162 and $462852 \mathrm{MJ} \mathrm{ha}^{-1}$ ) registered highest 
total output energy than rest of other treatments and at par with treatment $\mathrm{T}_{6}-125 \% \mathrm{RDN}+25 \% \mathrm{~N}$ through $\mathrm{FYM}$ (456708, 465670 and $461189 \mathrm{MJ} \mathrm{ha}^{-1}$ ) and again at par with treatment $\mathrm{T}_{1}-100 \%$ GRDF (452991, 464112 and $458552 \mathrm{MJ}$ $\mathrm{ha}^{-1}$ ) during first year, second year and in pooled mean over years, respectively. The lowest total output energy was observed in $\mathrm{T}_{2}-75 \% \mathrm{RDN}+25 \% \mathrm{~N}$ through FYM (429312, 442617 and $435965 \mathrm{MJ} \mathrm{ha}^{-1}$ ) during both the years and when the data pooled over years. Mandal et al. (2002) ${ }^{[3]}$ revealed that highest total bioenergy output of the crop production system was observed in soybean - wheat crop sequence.

\section{Energy input}

Numerically treatment $\mathrm{T}_{6}-125 \% \mathrm{RDN}+25 \% \mathrm{~N}$ through $\mathrm{FYM}$ exhibited highest values of total input energy (72475, 72910 and $72693 \mathrm{MJ} \mathrm{ha}^{-1}$ ) than rest of other treatments and was followed by treatment $\mathrm{T}_{1}-100 \% \operatorname{GRDF}(71875,72310$ and $72093 \mathrm{MJ} \mathrm{ha}^{-1}$ ) during first year, second year and mean over years. The lowest energy input was observed in treatment $\mathrm{T}_{3^{-}}$ $75 \% \mathrm{RDN}+25 \%$ through VC $(67975,68410$ and $68193 \mathrm{MJ}$ $\left.\mathrm{ha}^{-1}\right)$.

\section{Energy balance}

The various fertilizer levels to preceding sweet corn crop significantly influenced the total energy balance. The $\mathrm{T}_{7}$ $125 \% \mathrm{RDN}+25 \% \mathrm{~N}$ through $\mathrm{VC}$ recorded maximum total energy balance $\left(385966,396152\right.$ and $391059 \mathrm{MJ}^{-1}$ ) than rest of other treatments and $\mathrm{T}_{6}-125 \% \mathrm{RDN}+25 \% \mathrm{~N}$ through FYM (384233, 392760 and $\left.388497 \mathrm{MJ} \mathrm{ha}^{-1}\right)$ and again at par with treatment $\mathrm{T}_{1}-100 \%$ GRDF $(381116,391802$ and 386459 $\mathrm{MJ} \mathrm{ha}^{-1}$ ) during first year, second year and in pooled mean over years, respectively. The total energy balance was lowest in treatment $\mathrm{T}_{2}-75 \% \mathrm{RDN}+25 \% \mathrm{~N}$ through FYM (360425, 373295 and $366860 \mathrm{MJ} \mathrm{ha}^{-1}$ ). Similar results were also reported by Joshi and Billore (2004) ${ }^{[2]}$ that energy output, energy balance, energy balance per unit input and energy output per input ratio of cropping sequence were at higher magnitude due to conjunctive use of organic manures and biofertilizers.

\section{Energy balance per unit input}

The maximum energy balance per unit input was recorded in treatment $\mathrm{T}_{7}-125 \% \mathrm{RDN}+25 \% \mathrm{~N}$ through $\mathrm{VC}(5.39,5.50$ and 5.45) than rest of other treatments and at par with treatment $\mathrm{T}_{3}-75 \% \mathrm{RDN}+25 \%$ through $\mathrm{VC}(5.36,5.51$ and 5.44) during the year 2014, 2015 and pooled mean. The lowest energy balance per unit input was observed in treatment $\mathrm{T}_{4}-100 \% \mathrm{RDN}+25 \% \mathrm{~N}$ through FYM (5.23, 5.37 and 5.30). Vyas and Khandwe (2012) ${ }^{[4]}$ also showed that application of soybean residue + FYM 5 ton $\mathrm{ha}^{-1}+\mathrm{Zn} 5 \mathrm{~kg}$ $\mathrm{ha}^{-1}$ recorded highest energy input and gross energy output ratio in soybean-wheat cropping system.

\section{Energy use efficiency}

The treatment $\mathrm{T}_{7}-125 \% \mathrm{RDN}+25 \% \mathrm{~N}$ through $\mathrm{VC}(6.39$, 6.50 and 6.45) recorded significantly maximum energy use efficiency than rest of other treatments and at par with treatment $\mathrm{T}_{3}-75 \% \mathrm{RDN}+25 \%$ through $\mathrm{VC}(6.36,6.51$ and $6.44)$ during first year, second year and when the data pooled over years, respectively. The lowest energy use efficiency was observed in treatment $\mathrm{T}_{4}-100 \% \mathrm{RDN}+25 \% \mathrm{~N}$ through FYM $(6.23,6.37$ and 6.30) during first year, second year and when the data pooled over years, respectively. The energy evaluation studies in respect of energy output, energy balance, energy balance per unit input and energy output per unit input ratio showed that these parameters were significantly increased with successive increase in yield level.

Table 1: Yield $\left(\mathrm{q} \mathrm{ha}^{-1}\right)$ of sweet corn and potato during both years as influenced by different treatments

\begin{tabular}{|c|c|c|c|c|c|c|c|c|c|}
\hline & \multirow{2}{*}{ Treatment } & \multicolumn{2}{|c|}{ Green cob yield $\left(\mathbf{q ~ h a}^{-1}\right)$} & \multicolumn{2}{|c|}{ Green fodder yield (q ha-1) } & \multicolumn{2}{|c|}{ Tuber yield $\left(q\right.$ ha $\left.^{-1}\right)$} & \multicolumn{2}{|c|}{ Haulm yield $\left(q\right.$ ha $\left.^{-1}\right)$} \\
\hline & & 2014-15 & $2015-16$ & 2014-15 & $2015-16$ & \begin{tabular}{|l|}
$2014-15$ \\
\end{tabular} & 2015-16 & 2014-15 & 2015-16 \\
\hline \multicolumn{10}{|c|}{ Fertilizer levels to sweet corn } \\
\hline $\mathrm{T}_{1}:$ & $100 \%$ GRDF & 265.25 & 271.99 & 527.85 & 540.80 & 280.21 & 286.96 & 12.31 & 13.52 \\
\hline $\mathrm{T}_{2}:$ & $75 \%$ RDN + 25\% N through FYM & 249.75 & 256.25 & 509.49 & 520.66 & 260.35 & 272.35 & 10.46 & 10.54 \\
\hline $\mathrm{T}_{3}:$ & $75 \%$ RDN $+25 \% \mathrm{~N}$ through VC & 255.35 & 262.09 & 518.36 & 531.26 & 255.71 & 266.72 & 10.31 & 10.46 \\
\hline $\mathrm{T}_{4}:$ & $100 \%$ RDN $+25 \% \mathrm{~N}$ through FYM & 258.45 & 264.84 & 522.07 & 534.76 & 265.53 & 276.51 & 10.90 & 11.12 \\
\hline $\mathrm{T}_{5}:$ & $100 \% \mathrm{RDN}+25 \% \mathrm{~N}$ through VC & 260.74 & 267.04 & 524.09 & 536.58 & 261.65 & 274.71 & 10.66 & 10.97 \\
\hline $\mathrm{T}_{6}:$ & $125 \%$ RDN + 25\% N through FYM & 271.94 & 277.49 & 538.44 & 546.82 & 275.36 & 282.11 & 11.17 & 12.26 \\
\hline \multirow[t]{3}{*}{$\mathrm{T}_{7}:$} & $125 \% \mathrm{RDN}+25 \% \mathrm{~N}$ through VC & 275.55 & 281.55 & 542.83 & 554.19 & 271.55 & 278.95 & 11.06 & 11.17 \\
\hline & S. Em. \pm & 2.69 & 2.75 & 3.26 & 3.51 & 2.47 & 2.53 & 0.41 & 0.47 \\
\hline & C. D. at $5 \%$ & 7.98 & 8.25 & 9.80 & 10.55 & 7.41 & 7.59 & 1.22 & 1.41 \\
\hline \multicolumn{10}{|c|}{ Fertilizer levels to potato } \\
\hline$F_{1}:$ & $75 \%$ GRDF & & & & & 264.66 & 274.75 & 10.69 & 10.95 \\
\hline \multirow[t]{5}{*}{$\mathrm{F}_{2}:$} & $100 \%$ GRDF & & & & & 270.21 & 279.60 & 10.98 & 11.64 \\
\hline & S. Em. \pm & & & & & 2.44 & 1.04 & 0.13 & 0.11 \\
\hline & C. D. at $5 \%$ & & & & & NS & NS & NS & NS \\
\hline & Interaction & & & & & NS & NS & NS & NS \\
\hline & General mean & & & & & 267.44 & 277.18 & 10.83 & 11.29 \\
\hline
\end{tabular}


Table 2: Energy output, energy input, energy balance, energy balance/ unit input and energy use efficiency of sweet corn- potato sequence as influenced by different treatments

\begin{tabular}{|c|c|c|c|c|c|c|c|c|c|c|c|c|c|c|c|c|}
\hline \multirow{2}{*}{\multicolumn{2}{|c|}{ Treatment }} & \multicolumn{3}{|c|}{$\begin{array}{c}\text { Total output energy } \\
\left(\mathrm{MJ} \mathrm{ha}^{-1}\right)\end{array}$} & \multicolumn{3}{|c|}{$\begin{array}{c}\text { Total input energy } \\
\left(\mathrm{MJ} \mathrm{ha}^{-1}\right)\end{array}$} & \multicolumn{3}{|c|}{$\begin{array}{c}\text { Energy balance } \\
\left(\mathbf{M J} \text { ha }^{-1}\right)\end{array}$} & \multicolumn{3}{|c|}{$\begin{array}{c}\text { Energy balance per unit } \\
\text { input }\end{array}$} & \multicolumn{3}{|c|}{ Energy use efficiency } \\
\hline & & $\begin{array}{c}2014- \\
15\end{array}$ & \begin{tabular}{|c|}
$2015-$ \\
16
\end{tabular} & $\begin{array}{l}\text { Pooled } \\
\text { mean }\end{array}$ & $\begin{array}{c}2014- \\
15\end{array}$ & \begin{tabular}{|c|}
$2015-$ \\
16
\end{tabular} & $\begin{array}{c}\text { Pooled } \\
\text { mean }\end{array}$ & $\begin{array}{c}2014- \\
15\end{array}$ & $\begin{array}{c}2015- \\
16\end{array}$ & $\begin{array}{l}\text { Pooled } \\
\text { mean }\end{array}$ & \begin{tabular}{|c|}
$2014-$ \\
15
\end{tabular} & $\begin{array}{c}2015- \\
16\end{array}$ & $\begin{array}{c}\text { Pooled } \\
\text { mean }\end{array}$ & $\begin{array}{c}2014- \\
15\end{array}$ & $\begin{array}{c}2015- \\
16\end{array}$ & $\begin{array}{c}\text { Pooled } \\
\text { mean }\end{array}$ \\
\hline \multicolumn{17}{|c|}{ Fertilizer levels to sweet corn } \\
\hline $\mathrm{T}_{1}:$ & $100 \%$ GRDF & 452991 & 464112 & 458552 & 71875 & \begin{tabular}{|l|}
72310 \\
\end{tabular} & 72093 & 381116 & 391802 & 386459 & 5.30 & 5.42 & 5.36 & 6.30 & 6.42 & 6.36 \\
\hline $\mathrm{T}_{2}:$ & $\begin{array}{c}75 \% \text { RDN }+25 \% \mathrm{~N} \\
\text { through FYM }\end{array}$ & 429312 & 442617 & 435965 & 68887 & 69322 & 69105 & 360425 & 373295 & 366860 & 5.24 & 5.38 & 5.32 & 6.24 & 6.38 & 6.32 \\
\hline $\mathrm{T}_{3}:$ & $\begin{array}{c}75 \% \mathrm{RDN}+25 \% \mathrm{~N} \\
\text { through } \mathrm{VC}\end{array}$ & 432101 & 445594 & 438848 & 67975 & 68410 & 68193 & 364126 & 377184 & 370655 & 5.36 & 5.51 & 5.44 & 6.36 & 6.51 & 6.44 \\
\hline $\mathrm{T}_{4}:$ & $\begin{array}{c}100 \% \text { RDN }+25 \% \mathrm{~N} \\
\text { through FYM }\end{array}$ & 440126 & 453397 & 446762 & 70687 & 71122 & 70905 & 369439 & 382275 & 375857 & 5.23 & 5.37 & 5.30 & 6.23 & 6.37 & 6.30 \\
\hline $\mathrm{T}_{5}:$ & $\begin{array}{c}100 \% \mathrm{RDN}+25 \% \mathrm{~N} \\
\text { through VC }\end{array}$ & 439545 & 453873 & 446709 & 69787 & 70222 & 70005 & 369758 & 383651 & 376705 & 5.30 & 5.46 & 5.38 & 6.30 & 6.46 & 6.38 \\
\hline $\mathrm{T}_{6}:$ & $\begin{array}{c}125 \% \mathrm{RDN}+25 \% \mathrm{~N} \\
\text { through FYM }\end{array}$ & 456708 & 465670 & 461189 & 72475 & 72910 & 72693 & 384233 & 392760 & 388497 & 5.30 & 5.39 & 5.34 & 6.30 & 6.39 & 6.34 \\
\hline $\begin{array}{c}6 \mathrm{~T}_{7} \\
: \\
\end{array}$ & $\begin{array}{c}125 \% \mathrm{RDN}+25 \% \mathrm{~N} \\
\text { through VC }\end{array}$ & 457541 & 468162 & 462852 & 71575 & 72010 & 71793 & 385966 & 396152 & 391059 & 5.39 & 5.50 & 5.45 & 6.39 & 6.50 & 6.45 \\
\hline & S. Em. \pm & 2217 & 1449 & 1690 & - & - & - & 1867 & 1942 & 1902 & 0.03 & 0.018 & 0.002 & 0.03 & 0.019 & 0.003 \\
\hline & C. D. at $5 \%$ & 6726 & 4397 & 4829 & - & - & - & 5602 & 5827 & 5712 & 0.08 & 0.05 & 0.006 & 0.08 & 0.057 & 0.006 \\
\hline \multicolumn{17}{|c|}{ Fertilizer levels to potato } \\
\hline $\mathrm{F}_{1}:$ & $75 \%$ GRDF & 442627 & 455000 & 448814 & 67739 & 68174 & 67957 & 374888 & 386826 & 380857 & 5.53 & 5.67 & 5.60 & 6.53 & 6.67 & 6.60 \\
\hline $\mathrm{F}_{2}:$ & $100 \%$ GRDF & 445735 & 457716 & 451726 & 73193 & 73628 & 73411 & 372542 & 384088 & 378315 & 5.09 & 5.22 & 5.15 & 6.09 & 6.22 & 6.15 \\
\hline & S. Em. \pm & 1119 & 1140 & 1186 & - & - & - & 1119 & 1129 & 1129 & 0.02 & 0.06 & 0.001 & 0.02 & 0.02 & 0.002 \\
\hline & C. D. at $5 \%$ & 3356 & 3421 & 3559 & - & - & - & 3358 & 3387 & 3387 & 0.06 & 0.19 & 0.003 & 0.06 & 0.06 & 0.006 \\
\hline & Interaction & NS & NS & NS & - & - & - & NS & NS & NS & NS & NS & NS & NS & NS & NS \\
\hline & General mean & 444181 & 456358 & 450270 & 70466 & 70901 & 70684 & 373715 & 385457 & 379586 & 5.31 & 5.45 & 5.38 & 6.30 & 6.44 & 6.37 \\
\hline
\end{tabular}

\section{References}

1. Anonymous. Economic Survey of India- \& Company Affairs, Govt. of India, New Delhi, 2013.

2. Joshi OP, Billore SD. Fertilizer management in soybeanwheat cropping system. Indian J Agric. Sci. 2004; 74(8):430- 432.

3. Mandal KG, Saha KP, Ghosh PK, Hati KM Bandopadhyay KK. Bioenergy and economic analysis of soybean-based crop production system in Central India. Biomass and Bioenergy. 2002; 23(5):337-345.

4. Vyas MD, Khandwe Rupendra. Effect of integrated nutrient management on system productivity of soybeanwheat cropping system in Vindhyan Plateau of Madhya Pradesh. J Oilseeds Res. 2012; 29(1):41-44.

5. Kannan P, Saravanan A, Krishnakumar S, Natarajan SK. Biological properties of soil as influenced by different organic manures. Res. J Agric. and Biol. Sci. 2005; 1(2):181-183.

6. Meena KN, Ashok Kumar, Rana DS, Meena MC. Productivity and nutrient uptake of maize (Zea mays)-wheat (Triticum aestivum) cropping system under different bio-sources and nitrogen levels. Indian J Agron. 2011; 56(3):182-188.

7. Singh SP, Vinay Singh, Singh RV, Lakhan R. Effect of phosphorus and farmyard manure application on yield, content and uptake of nitrogen, phosphorus and sulphate by potato (Solanum tuberosum L.). Indian J Agron. 1996; 41(4):630-632.

8. Zeidan MS. Effect of organic manure and phosphorus fertilizers on growth, yield and quality of lentil plants in sandy soil. Res. J Agric. Biol. Sci. 2007; 3(6):748-752. 